\title{
Comparative Analysis of Machining Stainless Steel using Soluble and Vegetable oils as Cutting Fluids
}

\section{OGEDENGBE Temitayo Samson', AWE Peter ${ }^{2}$, JOSEPH Ojotu ljiwo ${ }^{3}$}

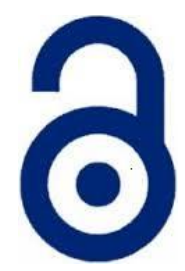

\author{
Received: 29 January 2019 \\ Accepted: 27 February 2019 \\ Published: 01 March 2019 \\ Publisher: Deer Hill Publications \\ (c) 2019 The Author(s) \\ Creative Commons: CC BY 4.0
}

\begin{abstract}
In this study, the performance of groundnut oil as an alternate cutting fluid was compared with that of soluble oil during machining of stainless steel. The temperature at the cutting zone, surface roughness and the chip formation were monitored under the two cutting conditions (soluble oil and vegetable oil). The machining parameters used were cutting speed $(75-135 \mathrm{rev} / \mathrm{min})$, feed rate $(0.01-0.05 \mathrm{~mm} / \mathrm{mm})$ and depth of cut $(0.01-0.08 \mathrm{~mm})$. The experiment was designed using Taguchi orthogonal array of Minitab 18 which generated a 9 run machining parameter mix for the experimentation. The Physiochemical properties of the various fluids were also analyzed to determine the properties and constituent elements of the cutting fluids. The actual machining of the stainless steel bar was done using a Colchester mastiff lathe machine. Results show that feed rate and cutting speed had the most significant effect on surface roughness during machining of stainless steel both with groundnut oil and soluble oil. Soluble oil was a better coolant but poorer in lubrication as vegetable oil reduced surface roughness more when used. Surface roughness value improved from $9.21 \mu \mathrm{m}$ during machining with soluble oil to $3.84 \mu \mathrm{m}$ during machining with groundnut oil which represented a $58.3 \%$ improvement. Hence, vegetable oil is therefore recommended as good alternative cutting fluid to soluble oil during machining of stainless steel.
\end{abstract}

Keywords: Energy consumption, Machine tools, Machining processes, Parameters

\section{INTRODUCTION}

Machining is a material removal process used in the industrial sector to produce workpieces with required shape, dimensions, and surface finish [1]. Cutting fluid (coolant) is any liquid or gas that is applied to the chip and/or cutting tool to improve cutting performance. A very few cutting operations are performed dry i.e. without the application of cutting fluids. Generally, it is essential that cutting fluids be applied to all machining operations. Cutting fluids have traditionally been used in machining operations to lubricate the chip-tool, tool-work piece interfaces, remove heat from the Work piece and cutting zone, flush away chips from the cutting area, and inhibit corrosion. While each of these four functions can be employed as justification for cutting fluid usage, it is widely believed that the primary functions of a cutting fluid are lubrication and cooling [2]. Currently, several types of conventional cutting fluids in used are classified according to their chemical formulation in straight oils and water soluble oils. Straight oils or neat oils are non-water-soluble fluids formulated to reduce the friction between the tool and both the chips and work piece. They can be mineral (petroleum based) and animal oil. Straight oils have excellent lubrication and corrosion resistance properties However, when inappropriately handled, they may result in skin problems and when cutting fluids evaporate they are distributed as vapor and micro-particles and may lead to breathing problems for the machine operator [3]. Disposal of the used cutting fluid is also a major challenge [4]. To cope with these problems, the necessity of using biodegradable fluids has recently been emphasized [5], [6]. And many researchers have carried out different research on the use of vegetable oil as an alternative, Vegetable oil is a biodegradable fluid that enhances the cutting performance, extend tool life and improve the surface finish. The effect of vegetable based cutting oil on cutting forces and power has been investigated [7]. Results showed that vegetable based cutting oils were better than

T. S. Ogedengbe ${ }^{1}$ 冈, P. Awe $\mathrm{A}^{2}$ and O.I. Joseph ${ }^{3}$

Department of Mechanical and Automotive Engineering

Elizade University, Ilara-Mokin

Ondo State, Nigeria

'E-mail: temitayo.ogedengbe@elizadeuniversity.edu.ng

2E-mail: peter.awe@elizadeuniversity.edu.ng

3E-mail: ojotu.joseph@elizadeuniversity.edu.ng 
the commercial mineral oil. A review on use of soya bean, rape seed and sunflower oils as a potential cutting fluid has been performed [8]. The three oils were found to be promising alternatives for mineral based oils due to their environmental friendly characteristics. A review on the use of vegetable oil based metal working fluids has been carried out. It was reported that castor, coconut, rapeseed and canola oils have promising future as metal working fluids [9]. A comparative analysis of AISI 1050 steel using N5-soluble oil and arachis oil in metal cutting operation has been carried out [1]. Result shows that arachis oil has a better lubricating performance than N5- soluble oil. An Investigation on the influence of vegetable based cutting fluids on cutting force during milling of aluminum metal matrix composites has been done [10]. Their result shows that palm oil suits better than the other vegetable based cutting fluids in terms of minimum cutting force requirement and minimum vibration. The performance of vegetable based oils in drilling austenitic stainless steel has been studied [11]. The effect of six cutting fluids on the tool was investigated by examining tool life, cutting forces and chip formation using a CNC vertical milling center. It was reported that vegetable based oil produced better surface finish than the mineral oil based cutting fluids. Efforts have been put into the development of local emulsifiers from local raw materials for cutting fluids [12]. Seventeen emulsifiers were prepared and cutting fluids were developed to replace the general mineral oil based cutting fluids used during machining. It was reported that the emulsifier that exhibited maximum reduction of surface tension gave the more stable cutting oil emulsion formulation. Mild steel has machined using palm oil and groundnut oil as cutting fluid with performance evaluation done to compare results [13]. Results show that Palm oil gave the highest thickness of $0.27 \mathrm{~mm}$ due to its better lubricating property. The effect of use of vegetable-oil based lubricants on chip formation and tool wear in drilling processes has been investigated [14]. Result showed that coconut oil gave the best machinability and least wear on the drill bit under same condition with others. A performance evaluation of melon and groundnut oils as metal cutting fluids has been carried out [15]. The cooling ability of the fluids were investigated while machining carbon steel through a close observation of the surface finish and the chip shape formed. It was reported that the use of melon oil resulted in the production of ductile and continuous chips. However, not much work has been done to compare the effect of semi synthetic oils and vegetable based oils on surface roughness and cutting temperature especially when machining stainless steel. The need to replace non-biodegradable mineral oils with a biodegradable oil as cutting fluid has therefore necessitated this study. This work is therefore, an approach at investigating the comparative effect of using vegetable oil (a vegetable based cutting fluid) and soluble oil as cutting fluids when machining stainless steel on a lathe machine.

\section{METHODOLOCY}

\subsection{Workpiece Material, Machine and Tools}

The design of experiment for this work was done. The work piece material used in this experimentation was a stainless steel bar of diameter $30 \mathrm{~mm}$ and length $1000 \mathrm{~m}$ acquired from Oshogbo-Osun state, Nigeria (Fig. 1). The turning of the workpiece was carried out on a manually operated center lathe (Lathe Colchester mastiff 1400). A high speed steel (HSS), AISI M-42 type (Fig. 2) with a nose radius of $0.5 \mathrm{~mm}$, back rake angle of $6^{\circ}$, side rake of $10^{\circ}$, end cutting edge of $12^{\circ}$ and side cutting edge of $12^{\circ}$ was used as the cutting tool. A data logger digital electronic temperature indicating Regulator model TED-2001 was used to monitor the temperature at the cutting zone during the machining operation. The thermocouple wire was attached to the tool holder at a $0.5 \mathrm{~mm}$ distance from tool tip to sufficiently capture cutting temperature during the machining process (Fig. 3).

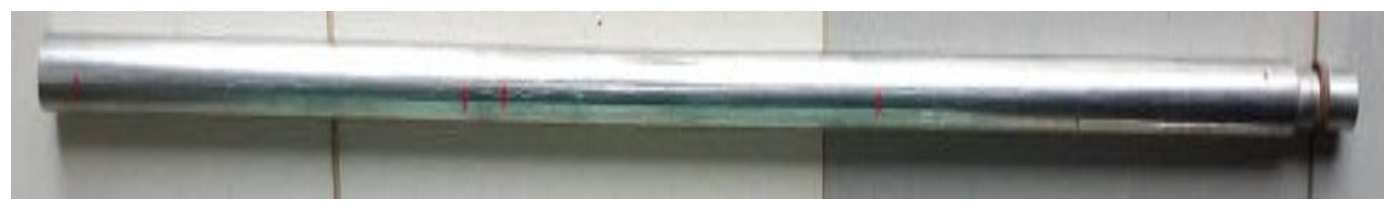

Figure 1: Stainless Steel Bar

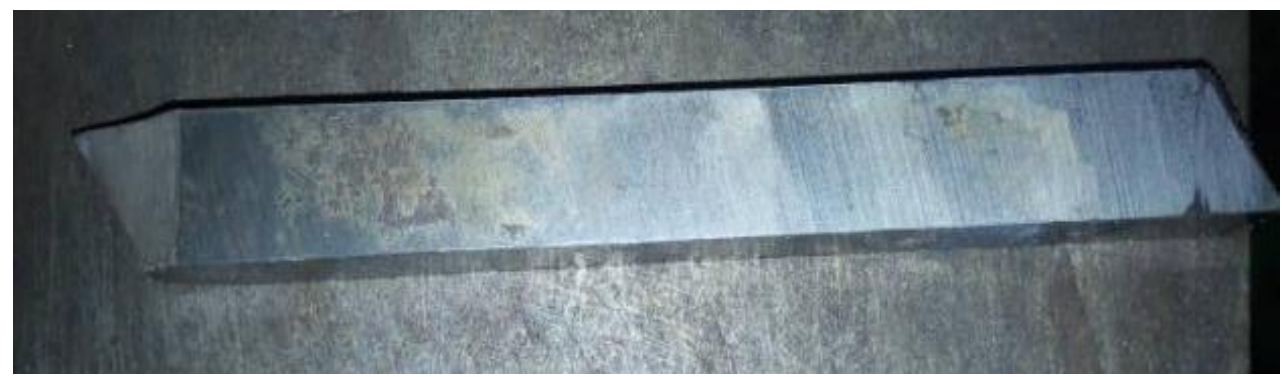

Figure 2: HSS Cutting tool 


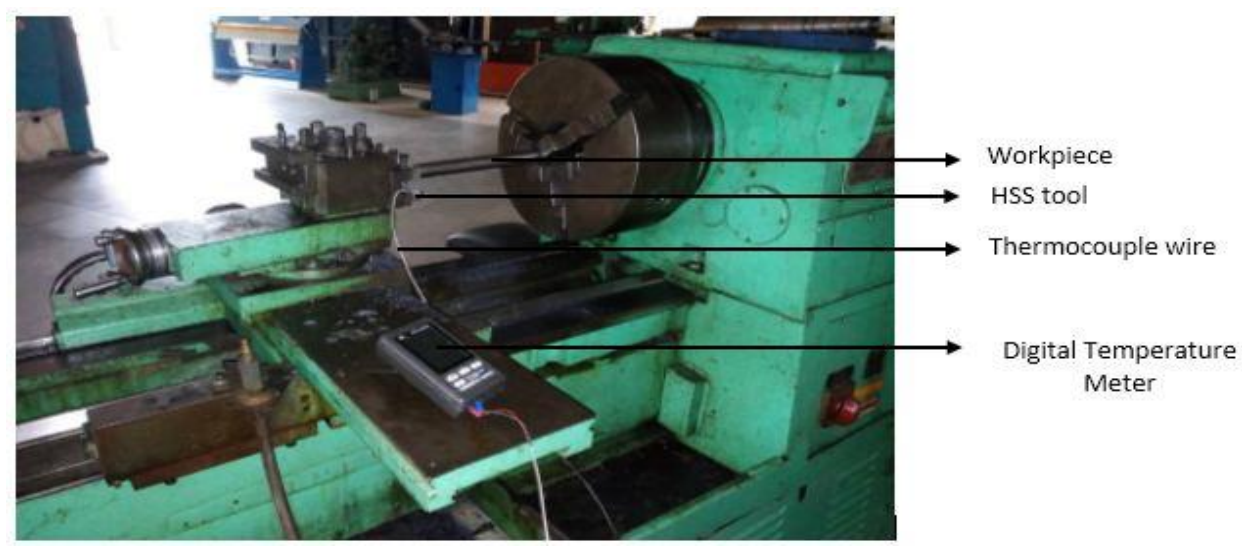

Figure 3: Experimental set up for machining process

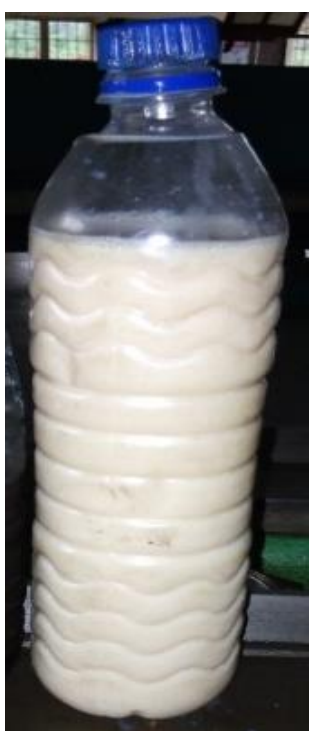

(a)

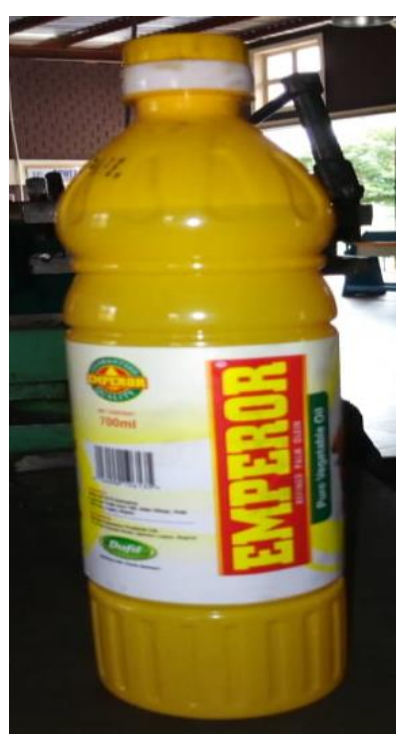

(b)

Figure 4: Cutting fluids used for experimentation (a) Soluble Oil, (b) Vegetable Oil

\subsection{Cutting Fluids}

The cutting fluids used in this study were soluble oil (Figure 4a) and groundnut oil (Figure 4b). Groundnut oil is a vegetable based cutting fluid which contains no destructive material and is environmental friendly. Soluble Oil used for the experiment was sourced from the school workshop when mixed with water, the soluble oil formed an emulsion that gave a milky appearance. The high oil content provides excellent physical lubricity for the cutting operation as well as protection for the machine tool. The composition of the soluble oil was $80 \%$ water and $20 \%$ based oil.

\subsubsection{Analysis of Cutting Fluids}

The analysis of the cutting fluids used was done. Relative Densities (Specific Gravity) was tested by Hydrometer Method (ASTM D 1298), the Flash-point by pensky-martens closed cup tester ASTM D93. PH was tested using the $\mathrm{PH}$ meter, and finally the acid value and saponification were carried out by titration. The same method was carried out for the two oil samples respectively. Table 1 Shows results of the analysis.

\subsubsection{Design of Experiment}

The Taguchi method from Minitab software version 18.0 was used for this work and a L9 orthogonal array was generated. The process parameters used for this study were cutting speed, feed rate and depth of cut. The process parameters and their levels are shown in Table 2. An orthogonal array was generated which guided the machining process as shown in Table 3. 
Table 1: Results of Physicochemical Analysis

\begin{tabular}{lccc}
\hline \multicolumn{1}{c}{ Properties Analyzed } & Vegetable Oil & Soluble Oil & Mixed Soluble Oil \\
\hline pH value & 5.6 & 7.1 & 6.8 \\
Saponification $\left(\mathrm{mgKOHg}^{-1}\right)$ & 72 & 79 & 85 \\
Acid value $\left(\mathrm{mgKOH}^{-1}\right)$ & 3.2 & 6.2 & 5.5 \\
Density $(\mathrm{g})$ & 40.65 & 41.34 & 42.65 \\
Flash point $\left({ }^{\circ} \mathrm{C}\right)$ & 117 & 114 & 80 \\
Viscosity $\left(40^{\circ} \mathrm{C}\right)\left(\mathrm{mm}^{2} / \mathrm{sec}\right)$ & 80 & 46 & 68 \\
\hline
\end{tabular}

Table 2: Process and their levels for dry and cooled machining

\begin{tabular}{cccc}
\hline Factor & $\begin{array}{c}\text { Spindle Speed } \\
(\mathrm{m} / \mathrm{min})\end{array}$ & $\begin{array}{c}\text { Feed Rate } \\
(\mathrm{mm} / \mathrm{rev})\end{array}$ & $\begin{array}{c}\text { Depth of Cut } \\
(\mathrm{mm})\end{array}$ \\
\hline Level 1 & 75 & 0.01 & 0.01 \\
Level 2 & 100 & 0.03 & 0.05 \\
Level 3 & 135 & 0.05 & 0.08 \\
\hline
\end{tabular}

Table 3: Orthogonal Array for machining from Minitab

\begin{tabular}{ccc}
\hline $\begin{array}{c}\text { Spindle Speed } \\
\mathrm{m} / \mathrm{min}\end{array}$ & $\begin{array}{c}\text { Feed rate } \\
\mathrm{mm} / \mathrm{rev}\end{array}$ & $\begin{array}{c}\text { Depth of Cut } \\
\mathrm{mm}\end{array}$ \\
\hline 75 & 0.05 & 0.1 \\
75 & 0.10 & 0.5 \\
75 & 0.40 & 0.8 \\
100 & 0.05 & 0.1 \\
100 & 0.10 & 0.5 \\
100 & 0.40 & 0.8 \\
135 & 0.05 & 0.1 \\
135 & 0.10 & 0.5 \\
135 & 0.40 & 0.8 \\
\hline
\end{tabular}

\subsection{Experimentation}

The machining experiment was carried out by turning of the workpiece on a manually operated center Lathe, each work piece was mounted on a three jaw self-centering chuck of the Lathe machine and properly secured using the chuck key. The cutting tool was mounted on the lathe tool post or tool holder after it has been grounded to the correct clearance and rake angles and in each experimental run, a fresh cutting tool was used for a fixed cutting time of not more than 20 minutes. The tool post was adjusted until approximately perpendicular to the work piece. The cutting temperature (temperature at the cutting zone) was measured using the temperature monitor. The work piece (stainless steel) was machined using the orthogonal array as shown in Table 3. The orthogonal array generated a 9-run machining mix which was used both for machining with soluble oil and groundnut oil as cutting fluids. The workpiece was measured before and after each machining step and weight values were recorded to calculate material removal rate.

\section{RESULTS AND DISCUSSIONS}

The experiment was performed and numerical values obtained, these values (results) were analyzed using Minitab 18 based on signal-to-noise $(S / N)$ ratio. Smaller-is-better $S / N$ ratio was chosen for Surface roughness (SR) since smaller $S R$ indicates better performance of the process.

\subsection{Mean effects of $S / N$ on Surface Roughness}

Tables 4 and 5 shows the experimental surface roughness result and response table for $S / N$ ratio obtained for both machining with vegetable oil and soluble oil based cutting fluid. Minitab 18 allocates ranks based on the delta values; rank 1 to the highest delta value, shows that the feed rate (rank 1) had the strongest effect on surface roughness, second highest (rank 2) which is Spindle speed and lastly is the depth of cut (rank 3) for both machining condition as shown in table 5 . Based on the analysis of the $\mathrm{S} / \mathrm{N}$ ratio, from the table the optimal machining performance for the surface roughness was obtained at $75 \mathrm{~m} / \mathrm{min}$ spindle speed (level 1);0.40mm/rev feed rate (level 3);0.05mm depth 
of cut (level 2) for vegetable oil based cutting fluid, and $75 \mathrm{~m} / \mathrm{min}$ spindle speed (level 1);0.40mm/rev feed rate (level 3); $0.08 \mathrm{~mm}$ depth of cut (level 3) for soluble oil based cutting fluid. For both machining condition feed rate has the greatest effect on the surface roughness of the workpiece.

\subsection{Surface Roughness Analysis}

The maximum and minimum surface roughness values during machining using soluble oil as cutting fluid were $16.17 \mu \mathrm{m}$ and $9.21 \mu \mathrm{m}$, however during machining using groundnut oil as cutting fluid, the maximum and minimum surface roughness values were $8.26 \mu \mathrm{m}$ and $3.84 \mu \mathrm{m}$ this represented a $49 \%$ and $60 \%$ improvement in the surface profile. This improvement was due to the reduction in maximum temperature at the cutting zone which ensured a preservation of surface integrity. Groundnut oil was therefore a preferred cutting fluid for the reduction of surface roughness during machining of the stainless steel. Its ability to improve surface integrity more than soluble oil was due to the higher lubricating property it possesses. As seen in Figure 5, the surface roughness was generally lower when machining using vegetable oil as cutting fluid than when using soluble oil as cutting fluid. The results of physicochemical analysis done (Table 1) showed that vegetable oil had a larger viscosity $\left(80 \mathrm{~mm}^{2} / \mathrm{sec}\right)$ than soluble oil which had a viscosity of $68 \mathrm{~mm}^{2} / \mathrm{sec}$. The higher viscosity of vegetable oil played a major part in its ability to reduce surface roughness because of its higher lubricating ability therefore reducing more friction between workpiece and tool during turning than soluble oil, with a lower lubricating ability. Vegetable oil had a lower acid value (3.2 $\left.m g K O H g^{1}\right)$ hence had lower corrosive impact on the work piece than soluble oil with an acid value of $5.5 \mathrm{mgKOHg}$.

\subsection{Cutting Temperature Analysis}

The temperature at the cutting zone was monitored during the experimental runs. As shown in Figure 6 and Table 6 , the maximum temperature reduced from $305.1^{\circ} \mathrm{C}$ recorded during machining with groundnut oil to $172.1^{\circ} \mathrm{C}$ representing about $43 \%$ reduction in heat at cutting zone. During machining with soluble oil, the temperature drop from $160^{\circ} \mathrm{C}$ to $80.2^{\circ} \mathrm{C}$ represented about $50 \%$ heat reduction. This result shows soluble oil has a better performance in heat removal from the cutting zone than groundnut oil when used as a cutting fluid. This result agrees with the results of previous work carried out by Abdulkareem et al. [2], who reported that vegetable oil has better lubricating abilities than soluble oil when machining carbon steel and Adekunle et al [15] who reported soluble oil as a better coolant than vegetable oil. However, the Flash point value for vegetable oil $\left(117^{\circ} \mathrm{C}\right)$ was higher than that of soluble oil $\left(80^{\circ} \mathrm{C}\right)$ hence, vegetable oil was therefore a preferred cutting fluid because it had a lower volatility and therefore reduced the possibility of hazard during use. This results agrees with $\mathrm{V}$. Koushik [9].

Table 4: Experiment layout, results and $\mathrm{S} / \mathrm{N}$ ratios of surface roughness using vegetable oil and soluble oil

\begin{tabular}{ccccccc}
\hline $\begin{array}{c}\text { Spindle } \\
\text { Speed } \\
(\mathrm{m} / \mathrm{min})\end{array}$ & $\begin{array}{c}\text { Feed rate } \\
(\mathrm{mm} / \mathrm{rev})\end{array}$ & $\begin{array}{c}\text { Depth of Cut } \\
(\mathrm{mm})\end{array}$ & \begin{tabular}{c} 
Vegetable oil \\
\cline { 4 - 6 }
\end{tabular} & & $\begin{array}{c}\text { Surface roughness } \\
\mu \mathrm{m}\end{array}$ & \multicolumn{2}{c}{ S/N Ratio } & $\begin{array}{c}\text { Surface roughness } \\
\mu \mathrm{m}\end{array}$ & S/N Ratio \\
\hline 75 & 0.05 & 0.01 & 4.67 & -13.3863 & 9.84 & -19.8599 \\
75 & 0.10 & 0.05 & 7.24 & -17.1848 & 14.23 & -23.0641 \\
75 & 0.40 & 0.08 & 8.26 & -18.3396 & 16.17 & -24.1742 \\
100 & 0.05 & 0.05 & 4.22 & -12.5062 & 9.49 & -19.5453 \\
100 & 0.10 & 0.08 & 6.01 & -15.5775 & 13.28 & -22.4640 \\
100 & 0.40 & 0.01 & 7.99 & -18.0509 & 14.77 & -23.3876 \\
135 & 0.05 & 0.08 & 3.84 & -11.6866 & 9.21 & -19.2852 \\
135 & 0.10 & 0.01 & 5.21 & -14.3368 & 12.65 & -22.0415 \\
135 & 0.40 & 0.05 & 6.99 & -16.8895 & 13.12 & -22.3587 \\
\hline
\end{tabular}

Table 5: Response Table for Signal to Noise Ratios

\begin{tabular}{ccccccc}
\cline { 2 - 7 } Level & \multicolumn{3}{c}{ Vegetable Oil } & \multicolumn{3}{c}{ Soluble Oil } \\
\cline { 2 - 7 } & $\begin{array}{c}\text { Spindle speed } \\
(\mathrm{m} / \mathrm{min})\end{array}$ & $\begin{array}{c}\text { Feed rate } \\
(\mathrm{mm} / \mathrm{rev})\end{array}$ & $\begin{array}{c}\text { Depth of Cut } \\
(\mathrm{mm})\end{array}$ & $\begin{array}{c}\text { Spindle speed } \\
(\mathrm{m} / \mathrm{min})\end{array}$ & $\begin{array}{c}\text { Feed rate } \\
(\mathrm{mm} / \mathrm{rev})\end{array}$ & $\begin{array}{c}\text { Depth of Cut } \\
(\mathrm{mm})\end{array}$ \\
\hline 1 & $-16.31^{*}$ & -12.53 & -15.26 & $-22.37^{*}$ & -19.56 & -21.76 \\
2 & -15.38 & -15.70 & $-15.53^{*}$ & -21.80 & -22.52 & -21.66 \\
3 & -14.30 & $-17.76^{*}$ & -15.20 & -21.23 & $-23.31^{*}$ & $-21.97^{*}$ \\
Delta & 2.00 & 5.23 & 0.33 & 1.14 & 3.74 & 0.32 \\
Rank & 2 & 1 & 3 & 2 & 1 & 3 \\
\hline
\end{tabular}

Optimum level: * 
Table 6: Temperature Obtain at Various Machining Condition

\begin{tabular}{cccccc}
\hline Run & $\begin{array}{c}\text { Spindle Speed } \\
\mathrm{m} / \mathrm{min}\end{array}$ & $\begin{array}{c}\text { Feed rate } \\
\mathrm{mm} / \mathrm{rev}\end{array}$ & $\begin{array}{c}\text { Depth of Cut } \\
\mathrm{mm}\end{array}$ & \multicolumn{2}{c}{ Stainless Steel } \\
\cline { 5 - 6 } & 75 & 0.05 & 0.01 & $\begin{array}{c}\text { Temperature }\left({ }^{\circ} \mathrm{C}\right) \\
\text { Vegetable Oil }\end{array}$ & $\begin{array}{c}\text { Temperature }\left({ }^{\circ} \mathrm{C}\right) \\
\text { Soluble Oil }\end{array}$ \\
\hline 1 & 75 & 0.10 & 0.05 & 201.3 & 100.4 \\
3 & 75 & 0.40 & 0.08 & 186.4 & 91.7 \\
4 & 100 & 0.05 & 0.05 & 271.1 & 80.2 \\
5 & 100 & 0.10 & 0.08 & 268.4 & 120.4 \\
6 & 100 & 0.40 & 0.01 & 260.1 & 111.3 \\
7 & 135 & 0.05 & 0.08 & 305.1 & 103.7 \\
8 & 135 & 0.10 & 0.01 & 287.3 & 160.1 \\
9 & 135 & 0.40 & 0.05 & 264.9 & 151.2 \\
\hline
\end{tabular}

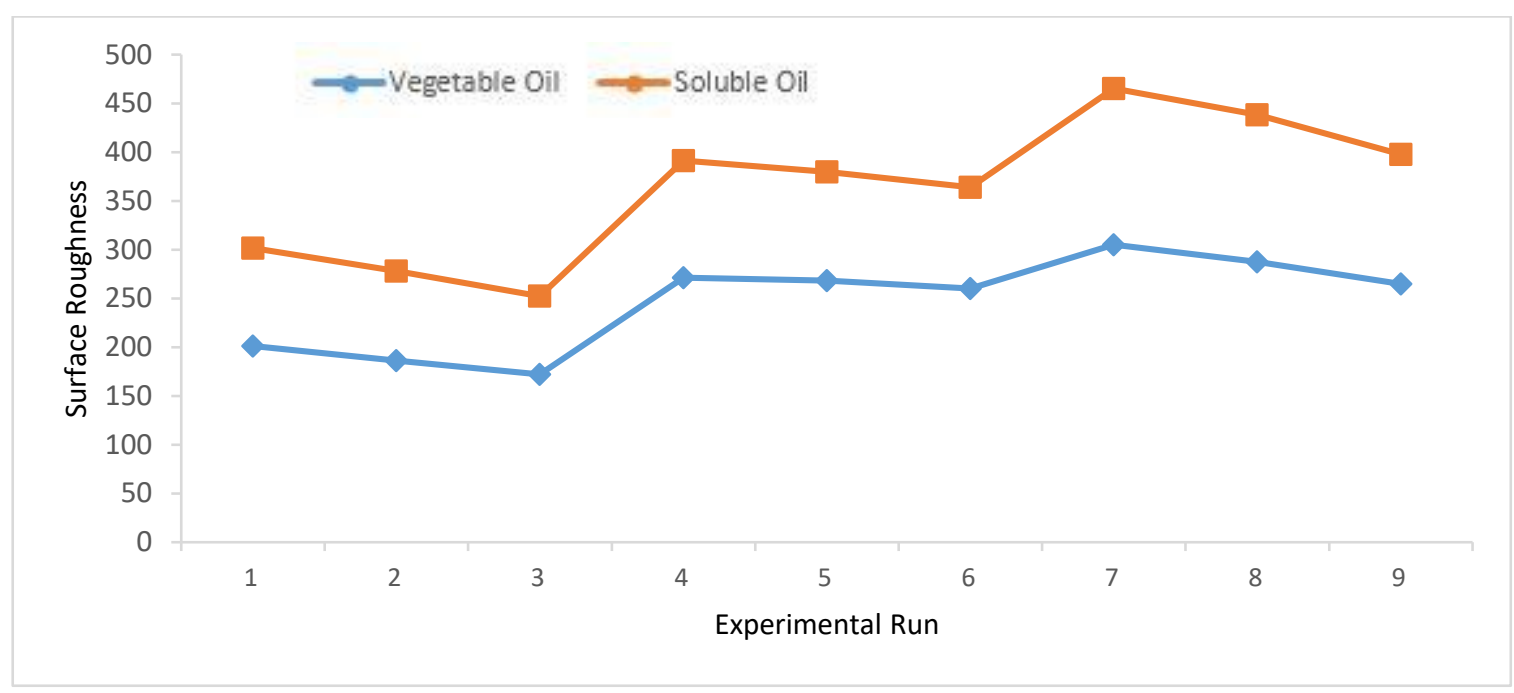

Figure 5: Surface roughness for Experimental runs suing various cutting fluids

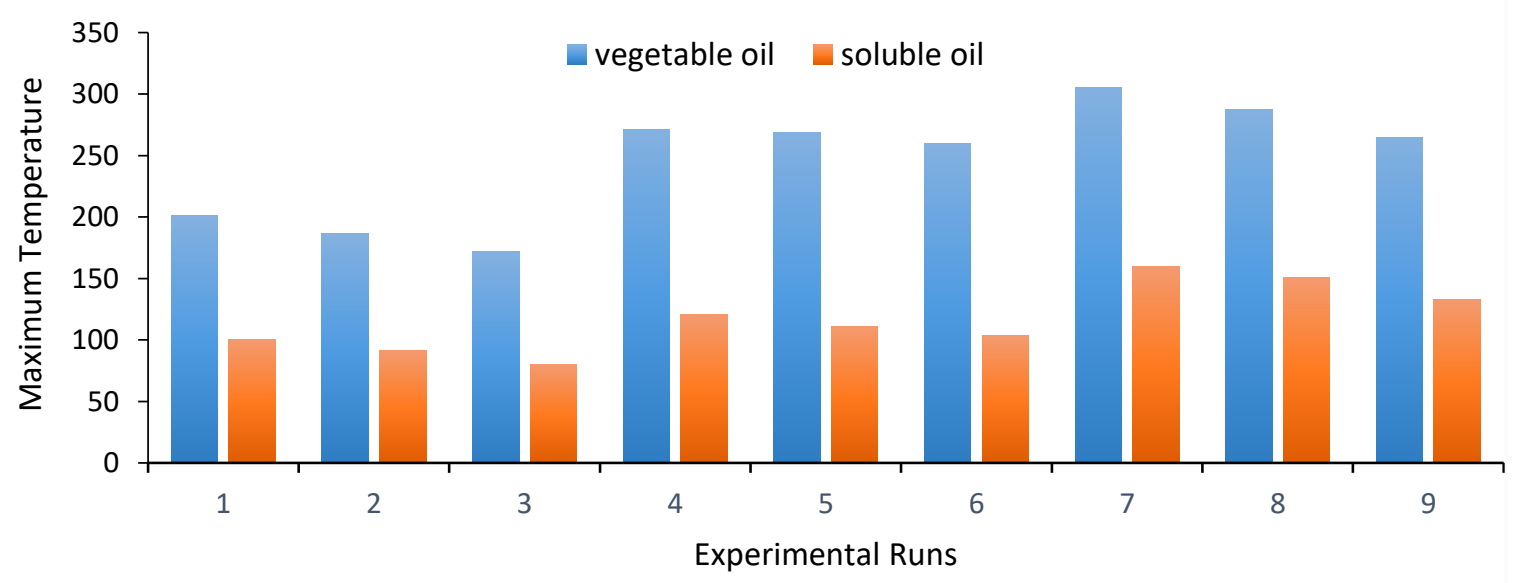

Figure 6: Maximum temperature attained during machining with various cutting fluids. 


\section{CONCLUSIONS}

A set of experimental investigations to consider the effect of using soluble oil and vegetable oil as cutting fluid during machining stainless steel has been successfully attempted. The following conclusions have been reached at the end of the experiment:

1. Feed rate and cutting speed had a significant effect on the surface quality of stainless steel during machining. Feed rate was the most significant control factor on the surface roughness during machining using vegetable oil and soluble oil. Depth of cut had no significant effect on surface quality of machined steel.

2. Vegetable oil performed more favorably as a lubricant as it produced a workpiece with a better surface finish than soluble oil during machining of stainless steel. This improvement represented a $49 \%$ and $60 \%$ improvement in the maximum and minimum values of surface profile comparing both vegetable and soluble oils as cutting fluid.

3. Soluble oil performed better in temperature reduction at the cutting zone as it reduced temperature at cutting zone by $50 \%$ while vegetable oil was only able to reduce temperature at cutting zone by $43 \%$. The overall results are summarized below:

However, it can be concluded that vegetable oil produced a better surface finish and hence it is evident that soluble oil based cutting fluid can be replaced with vegetable oil based cutting fluid.

\section{ACKNOWLEDGEMENT}

The authors wish to appreciate the efforts of Mr Olusoji Ajayi of Central laboratory of Elizade University and Mr. Aladejana Yezeed of Mechanical Engineering Department of Elizade University for their support and assistance during this study.

\section{REFERENCES}

1. Bissey-Breton S., Vignal V., Herbst F. \& Coudert J.B. (2016), "Influence of Machining on the Microstructure, Mechanical Properties and Corrosion Behaviour of a Low Carbon Martensitic Stainless Steel”, Procedia CIRP, 46, $331-335$.

2. Abdulkareem S., Ogedengbe T.S., Aweda J.O. \& Khan A.A. (2017). Comparative Analysis of AISI 1050 Steel Using N5-Soluble Oil and Arachis Oil in Metal Cutting Operation, Proceedings of the 30th AGM and International Conference of the Nigerian Institution for Mechanical Engineers. Kaduna, 195 - 206

3. Sokovic, M. \& Mijanovic, K. (2001). Ecological aspects of the Cutting Fluids and Its Influence on Quantifiable Parameters of the Cutting Processes, Journal of Material Processing Technology, 109 (1-2), 181- 189.

4. Deepak Joel J. R., Leo Dev K., Wins, Anil Raj \& Anuja Beatrice B. (2014) Optimization of Cutting Parameters and Fluid Application Parameters during Turning of OHNS Steel, 12th global congress on manufacturing and management, GCMM

5. Lawal, S. A., Choudhury, I. A., \& Nukman, Y. (2012). Application of vegetable oil-based metalworking fluids in machining ferrous metals - a review. International Journal of Machine Tool and Manufacture, 52(1), 1-12

6. Krishna P. V., Srikant, R. R., \& Rao, D. N. (2011). Solid lubricants in machining. Proceedings of the Institution of Mechanical Engineers, Part J: Journal of Engineering Tribology, 225(4), 213-227.

7. Belluco, W. \& De Chiffre L. (2001). Testing of vegetable-based cutting fluids by hole-making operations. Lubrication Engineering, 57, 12-16.

8. Shashidhara Y. \& Jayaram S. (2010), Vegetable oils as a potential cutting fluid- an evolution, Tribology International, 43, 1073-1081.

9. Vaibhav Koushik A.V, Narendra Shetty. S \& Ramprasad.C (2012), Vegetable Oil-Based Metal Working Fluids-A Review, International Journal on Theoretical and Applied Research in Mechanical Engineering (IJTARME), Volume-1, Issue-1, 2012, ppg 95-101.

10. Shankar S., Mohanraj T. \& Ponappa K. (2017). Influence of vegetable based cutting fluids on cutting force and vibration signature during milling of aluminium metal matrix composites. Jurnal Tribology, 12, 1-17.

11. W. Belluco and L. De Chiffre, Performance evaluation of vegetable-based oils in drilling austenitic stainless steel, Journal of Materials Processing Technology 148 (2004), pp. 171-176.

12. A. M. Al Sabagh, N. A. Maysour, N. M. Nasser \& M. R. Sorour (2006) Some Cutting Oil Formulations Based on Local Prepared Emulsifiers Part I: Preparation of Some Emulsifiers Based on Local Raw Materials to Stabilize Cutting Oil Emulsions, Journal of Dispersion Science and Technology, 27:2, 239 250, DOI: $10.1080 / 01932690500267215$

13. Kolawole S.K. and Odusote J.K. (2013) - Performance Evaluation of Vegetable Oil-Based Cutting Fluids in Mild Steel Machiningll, Chemistry and Materials Research, ISSN 2224- 3224 (Print) ISSN 2225- 0956 (Online), Vol.3 No.9, page 35-45 
14. Fairuz M.A., NurulAdlina M.J., Azmi A.I., Hafiezal M.R.M., Leong K.W., "Investigation of Chip Formation and Tool Wear in Drilling Process Using Various Types of Vegetable-Oil Based Lubricants", Applied Mechanics and Materials, Vols. 799-800, 2015, pp. 247-250.

15. Adekunle A.S., Adebiyi K.A., Durowoju M.O. (2015). Performance Evaluation of Groundnut Oil and Melon Oil as cutting fluids in Machining Operation, ACTA TEHNICA CORVINIENSIS - Bulletin of Engineering, Tome VIII [2015] Fascicule 1 [January - March], ISSN: 2067 - 3809 